UDK 577.1 : 61

ISSN 1452-8258

\title{
IDENTIFICATION OF SERUM miR-378 AND miR-575 AS DIAGNOSTIC INDICATORS AND PREDICTING SURGICAL PROGNOSIS IN HUMAN EPILEPSY
}

\author{
IDENTIFIKACIJA U SERUMU miR-378 I miR-575 KAO DIJAGNOSTIČKIH POKAZATELJA \\ I PREDVIĐANJA HIRURŠKE PROGNOZE U HUMANOJ EPILEPSIJI
}

\author{
XiuXiu Li, ZhiQing Gao, Mei Ling Ma, Li Li, ShiFeng Guo \\ Department of Neurology, Linyi Central Hospital, Linyi City, Shandong Province, 276000, China
}

\section{Summary}

Background: Epilepsy (EP) is a common neurological disorder which is characterized by excessive abnormal synchronization of neuronal discharges in the brain due to chronic recurrent seizures of multiple etiologies. Variety of microRNAs have been associated with the occurrence and development of EP. This study aimed to determine the aberrant expression of miR-378 and miR-575 in EP patients to validate their potential to distinguish EP from healthy patients.

Methods: RT-qPCR was used to determine the expressions of miR-378 and miR-575 from serum specimens of 106 EP and 103 control individuals. Clinical indicators between EP patients and controls were assessed. Based on surgical outcome, EP patients were further divided into Engel I-IV EP. The potentials of miR-378 and miR-575 in discriminating EP from healthy participants and predicting surgical prognosis were calculated by receiver operating characteristic (ROC) analysis.

Results: We found the miR-378 and miR-575 were significantly declined $(P<0.001)$ in Engel $I-I I$ and III-IV EP patients with no difference in clinical parameters compared. Moreover, miR-378 and miR-575 displayed high sensitivity, specificity, and accuracy in distinguishing EP patients and predicting surgical outcomes. Moreover, after surgical treatment, miR-378 and miR-575 levels were increased compared with those at admission, suggesting their potentials in treatment response.

Conclusions: miR-378 and miR-575 could be utilized as novel and non-invasive serum biomarkers in discriminating EP from healthy controls and predicting surgical outcome, shedding new insights on epileptogenesis and EP treatment.

Keywords: miR-378, miR-575, human epilepsy, serum biomarkers

Address for correspondence:

XiuXiu Li, Department of Neurology, Linyi Central Hospital, 17 Jiankang Road Yishui County, Linyi City, Shandong Province, 276000, China

e-mail: lily_xxdzz@outlook.com

\section{Kratak sadržaj}

Uvod: Epilepsija (EP) je uobičajen neurološki poremećaj koji se karakteriše prekomernom sinhronizacijom pražnjenja neurona u mozgu usled hroničnih ponovljenih napada različitih etiologija. Različite mikro RNK su povezane sa pojavom i razvojem EP. Ova studija je imala za cilj da odredi aberantnu ekspresiju miR-378 i miR-575 kod pacijenata sa EP kako bi potvrdila njihov potencijal da se ustanovi razlika između pacijenata sa EP i zdravih pacijenata.

Metode: RT-qPCR je korišćen da bi se odredila ekspresija miR-378 i miR-575 iz serumskih uzoraka 106 pacijenata sa EP i 103 kontrolna ispitanika. Izvršena je procena kliničkih pokazatelja kod pacijenata sa EP i kontrolnih ispitanika. Na osnovu ishoda hirurškog lečenja, pacijenti sa EP su dalje podeljeni na Engel I-IV EP. Analizom krive operativnih karakteristika (ROC) izračunat je potencijal koji imaju miR-378 i miR-575 i koji karakteriše pacijente sa EP u odnosu na zdrave učesnike istraživanja kako bi se predvideo tok lečenja.

Rezultati: Utvrdili smo da su miR-378 i miR-575 značajno smanjeni ( $P<0,001)$ kod pacijenata sa Engel I-II i III-IV EP bez razlika u upoređenim kliničkim parametrima. Štaviše, miR-378 i miR-575 su pokazali visoku osetljivost, specifičnost i tačnost u razlikovanju EP pacijenata i predviđanju ishoda. Dalje, nakon hirurškog lečenja, nivoi miR-378 i miR-575 su povećani u poređenju sa onima pri prijemu, što ukazuje na njihov potencijal u rekaciji na lečenje.

Zaključak: miR-378 i miR-575 se mogu koristiti kao novi i neinvazivni biomarkeri u serumu za diferencijaciju pacijenata sa EP od zdravih kontrolnih ispitanika i predviđanje hirurškog ishoda, otkrivajući nove uvide u epileptogenezu i lečenje EP.

Ključne reči: miR-378, miR-575, epilepsija kod ljudi, serumski biomarkeri 


\section{Introduction}

Epilepsy (EP) is a chronic brain disease with a long course that poses a severe threat to patients' physical and mental health (1). Seizures caused abnormal synchronous neuronal discharges (2), resulting in transient brain dysfunction and abnormalities in neuronal apoptosis, necrosis, and neurological deficits (3). In addition, EP was characterized by transience, unpredictability, and recurrence (4). About half of epilepsy patients had their onset in childhood and teenage years (5). So far, magnetic resonance imaging (MRI) and electroencephalography (EEG) have been able to help diagnose and differentiate epilepsy, whereas the assessment of anti-epileptic efficacy depended on EEG (6). However, EEG is expensive and time-consuming, which is not suitable for frequent and quick applications (7). Therefore, it is imperative to explore non-invasive and economic biomarkers to monitor EP development and evaluate the effectiveness of anti-epileptic treatment.

MicroRNAs (miRNAs) are endogenous singlestranded small RNA with approximately 22-24 nucleotides in length (8). These miRNAs are highly conserved and play a post-transcriptional role in regulating gene expressions (9). Several miRNAs are released from cells and circulate in the blood, show resistance to various RNA digesting enzymes, and are not affected by storage time, $\mathrm{pH}$, temperature, repeat freezing, and thawing (10). Because these are less affected by changes in the peripheral environment, miRNAs are used as biomarkers for various diseases, including epilepsy $(11,12)$. In recent years, there has been increasing evidence indicating that multiple miRNAs regulate EP. For instance, the expression of miR-106b-5p, let-7d-5p, miR-130a-3p and miR$146 a-5 p$ are upregulated in the serum of EP patients, while miR-15a-5p and miR-194-5p levels are downregulated (13). Moreover, miR-134 and miR-21-5p are downregulated among epileptic rats $(14,15)$. Meanwhile, multiple miRNAs have been associated with epileptogenesis and the progression of EP (16, 17). In a previous study, miR-378 and miR-575 are dysregulated during the onset of EP and post-treatment (18). However, the potential of miR-378 and miR-575 concerning EP diagnosis and outcome prediction remained unknown.

In the present study, we aimed to determine the aberrant expression of miR-378 and miR-575 in EP patients to determine the potential in differentiating EP from healthy individuals. Moreover, the dynamic changes of miR-378 and miR-575 during seizure onset and after surgical treatment were evaluated to validate their application in predicting EP surgical outcome.

\section{Materials and Methods}

\section{Samples collection}

A total of 106 individuals diagnosed with EP but remained untreated in Linyi Central Hospital were enrolled as the EP group from November 2017 to April 2020. The control group consisted of 103 healthy individuals who underwent a physical examination at our hospital during the same period. The EP group and the healthy group were age and sexmatched. All enrolled participants signed informed consent, and the Ethics Committee of Linyi Central Hospital approved the current study protocol. Inclusion criteria for the EP: (1) those who were eligible for primary EP according to the diagnostic and classification criteria of the International League Against Epilepsy (ILAE); (2) the time since the last seizure was less than 1 week; (3) organic lesions such as traumatic brain injury, developmental malformation of the brain, intracranial occupancy, and cerebral infarction were excluded by imaging examinations such as computed tomography (CT), MRI and EEG. In addition, EP patients with neurological and other systemic disorders, traumatic brain injury, or receiving psychotropic medications in the last three months were excluded.

$5 \mathrm{~mL}$ of blood sample was collected from EP patients and healthy controls after fasting and kept at room temperature for 3 hours. Then, the supernatant was aspirated into a sterilized EP tube. The sample was then centrifuged at $3000 \mathrm{r} / \mathrm{min}$ at room temperature for $10 \mathrm{~min}$. After centrifugation, samples were stored at $-80^{\circ} \mathrm{C}$ until use.

\section{$R T$-qPCR analysis}

The frozen serum samples, stored at $-80{ }^{\circ} \mathrm{C}$, were thawed at $4{ }^{\circ} \mathrm{C}$ in a refrigerator. $1.5 \mathrm{~mL}$ of each sample was dispensed in a centrifuge tube. Next, 1 $\mathrm{mL}$ TRIzol was added to each sample at room temperature for $5 \mathrm{~min}$. After lysis, $200 \mu \mathrm{L}$ of chloroform was added for $10 \mathrm{~min}$ and then centrifuged at $12,000 \mathrm{~g}$ for $15 \mathrm{~min}$ at room temperature. Afterwards, $1 \mathrm{~mL}$ of $75 \%$ alcohol was used to precipitate RNA and then centrifuged at $4{ }^{\circ} \mathrm{C}$ for $5 \mathrm{~min}$ at $7,500 \mathrm{~g}$. After washing, the RNA was placed for 15 min to dry RNA. Finally, $20 \mu \mathrm{L}$ DNase/RNase-free deionized water was added to dissolve the RNA extract. The samples were analyzed for RNA purity using a NANODROP 2000 spectrophotometer. Then, the reverse transcription kit, SuperScript $R$ Enzyme Mix, was used to prepare cDNA. The RTqPCR was performed in AXYGEN $0.2 \mathrm{~mL}$ 96-well PCR system with U6 RNA as the internal reference. The CT values of miR-378 and miR- 575 were derived at the end of the amplification reaction by fluorometric quantification and analyzed using the 2- $\Delta \Delta C T$ method. All the experiments were performed in triplicate. 


\section{Statistical analysis}

The experimental data, for normal distribution and variance homogeneity, were expressed in the form of mean \pm standard deviation ( $\bar{x} \pm s$ ). SPSS 22.0 software was used to statistically analyze the data obtained from each group, and an independent t-test and chi-square test were used for quantification. $\mathrm{P}<0.05$ was deemed statistically significant.

\section{Results}

\section{Clinicopathological information of all participants}

As shown in Table I, there were no significant differences in age, gender distribution, $\mathrm{BMI}$, and smoking history between EP patients and healthy controls.

Down-regulated miR-378 and miR-575 expressions in serum samples in EP patients

We used RT-qPCR to analyze and measure the expression levels of miR-378 and miR-575 in serum samples from EP patients and healthy volunteers. As highlighted in Figures $1 A$ and $1 B$, the expression of miR-378 and miR-575 were prominently increased in the EP group as compared with the healthy control $\left({ }^{\star * \star} \mathrm{P}<0.001\right)$.

Engel grades were applied to discriminate EP patients regarding seizure response to surgical treatment. According to the guidelines, Engel I was defined as free of disabling EP; Engel II was rare seizure after surgery; Engel III was deemed worth- while improvement of EP reduction after surgery; Engel IV was characterized as no improvement in seizure conditions. As depicted in Figures $2 A$ and $2 B$, Engel III-IV EP patients had significantly lower miR378 and miR-575 expressions than Engel I-II $\left({ }^{* * *} \mathrm{P}<0.001\right)$, suggesting the potentials of miR-378 and miR-575 in predicting surgical outcome.

Table I Clinical information of healthy individuals and patients with epilepsy.

\begin{tabular}{|c|c|c|c|}
\hline Parameters & $\begin{array}{l}\text { EP patients } \\
(\mathrm{n}=106)\end{array}$ & $\begin{array}{c}\text { Healthy } \\
(n=103)\end{array}$ & $P$ value \\
\hline \multicolumn{4}{|l|}{ Gender } \\
\hline Male & 57 & 52 & 0.6342 \\
\hline Female & 49 & 51 & \\
\hline Age & $29.5 \pm 7.2$ & $31.2 \pm 6.8$ & 0.0809 \\
\hline \multicolumn{4}{|c|}{ EP duration (years) } \\
\hline$\leq 5$ & 81 & I & I \\
\hline$>5$ & 25 & l & \\
\hline \multicolumn{4}{|c|}{ Smoking history } \\
\hline Yes & 44 & 46 & \multirow{2}{*}{0.6456} \\
\hline No & 62 & 57 & \\
\hline BMI $\left(\mathrm{kg} / \mathrm{m}^{2}\right)$ & $24.6 \pm 0.7$ & $25.0 \pm 0.5$ & 0.9555 \\
\hline miR-378 level & $0.47 \pm 0.17$ & $1.01 \pm 0.26$ & $<0.0001$ \\
\hline miR-575 level & $0.49 \pm 0.21$ & $1.03 \pm 0.24$ & $<0.0001$ \\
\hline
\end{tabular}

A

miR-378 expression

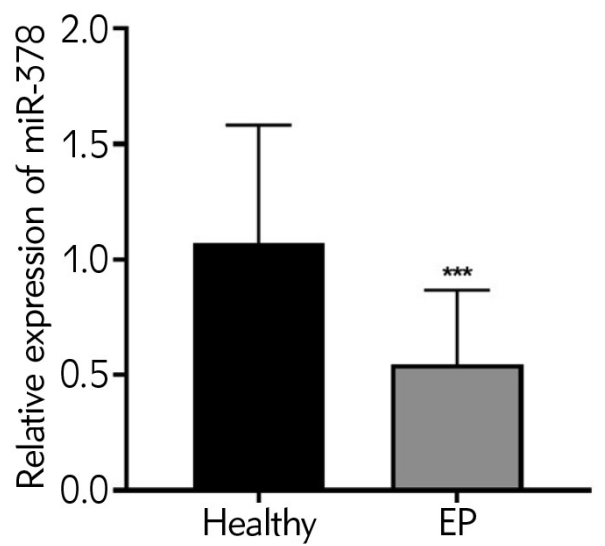

B

miR-575 expression

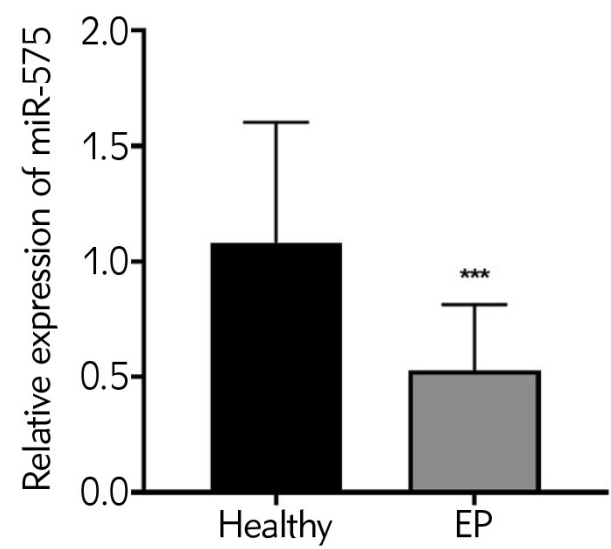

Figure 1 Aberrant expressions of miR-378 and miR-575 in serum samples from healthy controls and patients with EP. (A) Expressions of miR-378 were evaluated by qRT-PCR analysis. $* * * P<0.001$, EP vs Healthy. (B) Expressions of miR-575 were evaluated by qRT-PCR analysis. ${ }^{* * * P}<0.001$, EP vs Healthy. EP, epilepsy. 
A

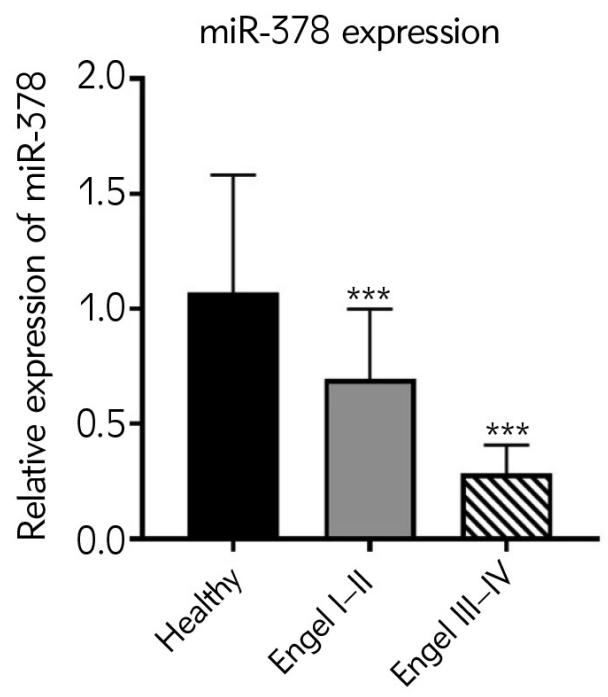

B

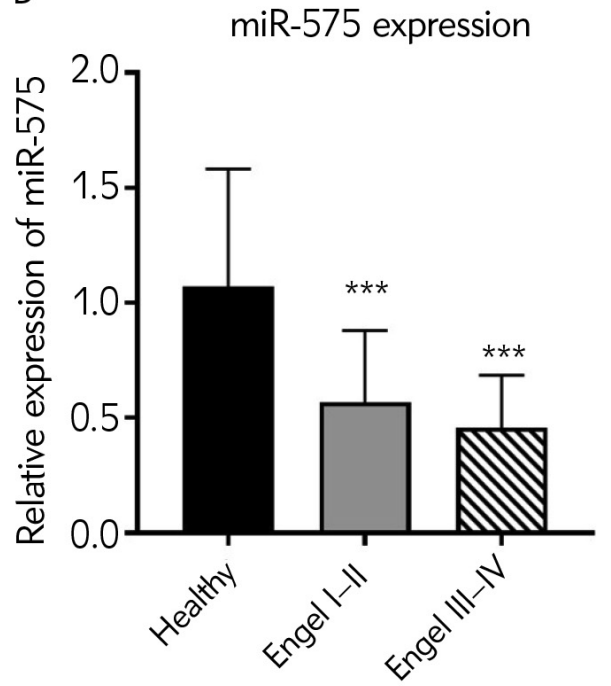

Figure 2 Different expressions of miR-378 and miR-575 in patients with EP according to Engel grades. (A) miR-378 expressions in Engel I-II and Engel III-IV EP patients. (B) miR-575 expressions in Engel I-II and Engel III-IV EP patients. $* * * P<0.001$, Engel I-II vs. Healthy, Engel III-IV vs. Healthy. EP, epilepsy.

A

ROC of miR-378: EP vs. Healthy

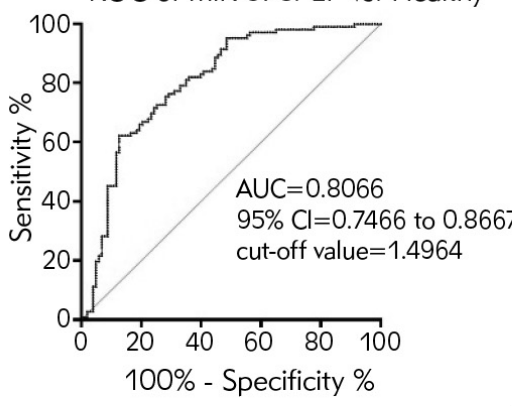

D

ROC of miR-575: EP vs. Healthy

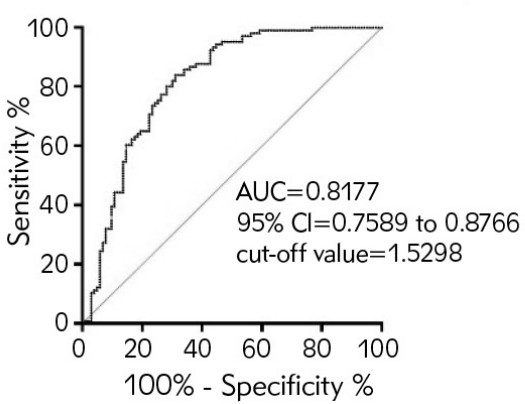

$B$ ROC of miR-378: Engel I-II vs. Healthy

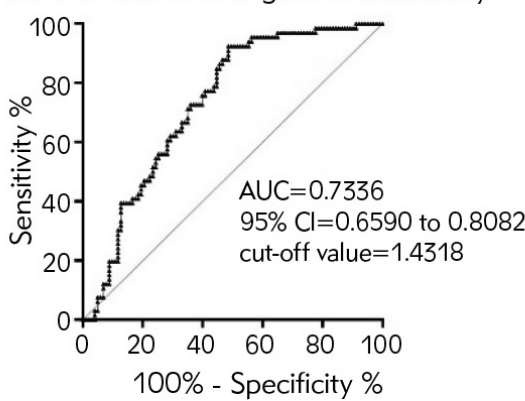

E ROC of miR-575: Engel I-II vs. Healthy

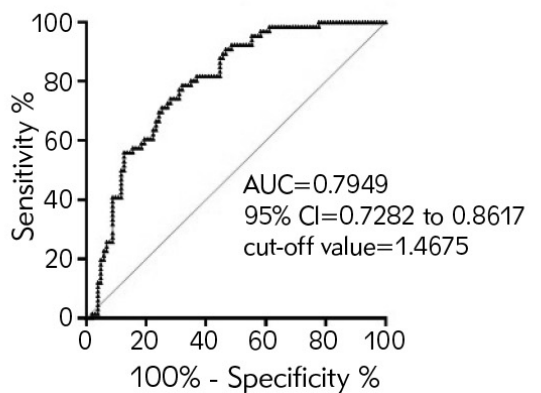

C

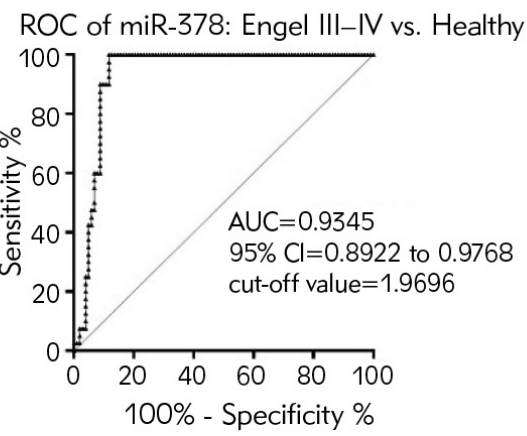

$\mathrm{F}$

ROC of miR-575: Engel III-IV vs. Healthy

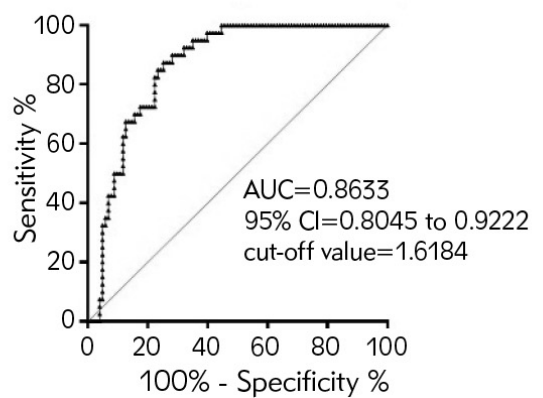

Figure $3 \mathrm{ROC}$ analysis of miR-378 and miR-575 in discriminating EP patients from healthy controls. (A) AUC of miR-378 in differentiating EP patients from healthy volunteers. (B) AUC of miR-378 in differentiating Engel I-II EP patients from healthy volunteers. (C) AUC of miR-378 in differentiating Engel III-IV EP patients from healthy volunteers. (D) AUC of miR-575 in differentiating EP patients from healthy volunteers. (E) AUC of miR-575 in differentiating Engel I-II EP patients from healthy volunteers. (F) AUC of miR-575 in differentiating Engel III-IV EP patients from healthy volunteers. 
A

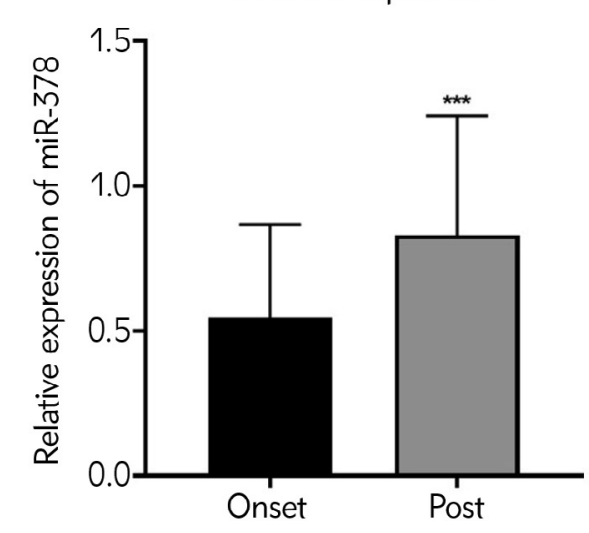

B

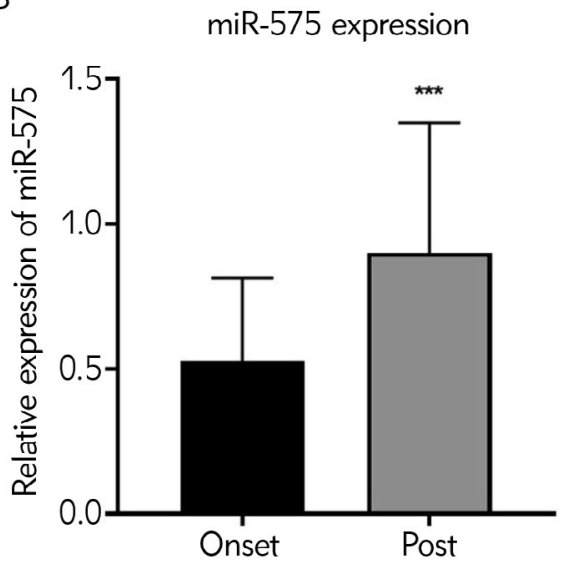

Figure 4 Dynamic expressions of miR-378 and miR-575 in EP patients before and after surgical treatment. (A) miR-378 expressions at seizure onset and post-seizure. (B) miR-575 expressions at seizure onset and post-seizure. ${ }^{* * * P<0.001, ~ P o s t ~}$ vs. Onset. Post, post treatment; onset, epilepsy onset.

Diagnostic performances of miR-378 and miR575 in distinguishing EP patients from healthy controls

ROC analysis was conducted to evaluate the capabilities of miR-378 and miR-575 abnormal expressions in discriminating EP from healthy controls. As demonstrated in Figure $3 A$ and $3 D$, miR-378 and miR-575 presented high accuracy, sensitivity, and accuracy in differentiating EP from healthy participants with the area under the curves (AUCs) of 0.8066 and 0.8177 , respectively (cut-off value = 1.4964 and 1.5298). Moreover, the AUCs of miR378 and miR-575 in distinguishing Engel I-II EP from healthy controls were 0.7336 and 0.7949 , respectively. Additionally, the AUCs of miR-378 and miR575 in distinguishing Engel III-IV EP from healthy controls were 0.9345 and 0.8933 , with the cut-off value of 1.9696 and 1.6184. Collectively, these results suggested that miR-378 and miR-575 were implicated in epileptogenesis and monitoring EP occurrence.

Dynamic levels of miR-378 and miR-575 before and after surgical treatment

After surgical treatment, the dynamic changes of miR-378 and miR-575 in EP samples were detected using qRT-PCR assay. As shown in Figures $4 A$ and $4 B$, the expression of miR-378 and miR-575 was augmented after treatment compared to those at seizure onset, implying that miR-378 and miR-575 may function as feasible biomarkers for EP treatment response $\left({ }^{* * *} \mathrm{P}<0.001\right)$.
Surgical outcomes regarding miR-378 and miR575 in $E P$

Giving that Engel grade could indicate the surgical outcome in EP, we further examine the AUCs of miR-378 and miR-575 between Engel I-II and Engel III-IV EP patients. As illustrated in Figure 5A, miR378 could serve as an accurate and high sensitive biomarker for predicting EP surgical prognosis, with an AUC of 0.8985 and a cut-off value of 1.7326 . On the contrary, miR-575 had no value in predicting EP surgery outcome with the AUC value of less than 0.8 (Figure 5B).

\section{Discussion}

Statistical reports showed that about 70 million people worldwide were affected by EP (19). In China, there were more than 9 million EP patients (20). The number of patients with refractory EP who have been treated regularly for more than 2 years was greater than 2 million, and the prevalence rate accounted for $7 \%$ of the world's population (21). The clinical manifestations of epilepsy were diverse, and the typology was complex with 4 common features, seizure, repetitive, transient, and stereotyped (22). Current treatments for EP included medication, surgery, dietary modifications, and gene therapy (23). Clinical studies have shown that $70 \%-80 \%$ of new EP patients can be controlled with anti-epileptic drugs (AEDs), and 60\%$70 \%$ of these patients can be discontinued after 2 to 5 years of treatment with AEDs (24). Some postoperative patients with EP still needed AEDs to control their symptoms.

Epileptogenesis is a process in which the inflammatory response, the formation of new synaptic and abnormal conduction pathways, and neuronal apop- 
A

ROC of miR-378: Engel III-IV vs. Engel I-II

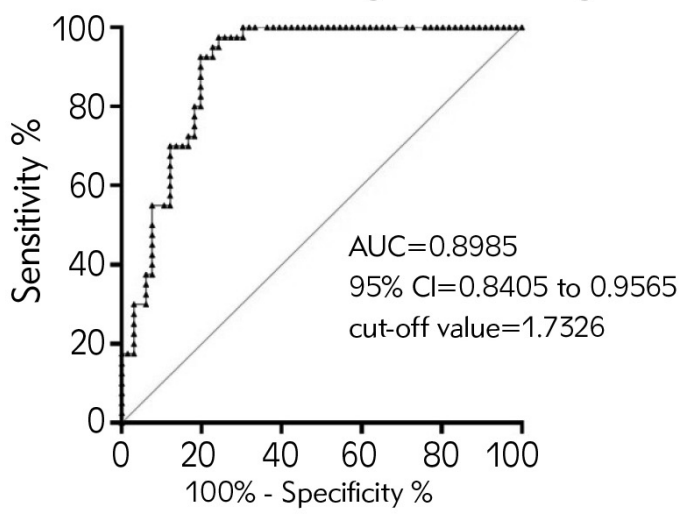

B

ROC of miR-575: Engel III-IV vs. Engel I-II

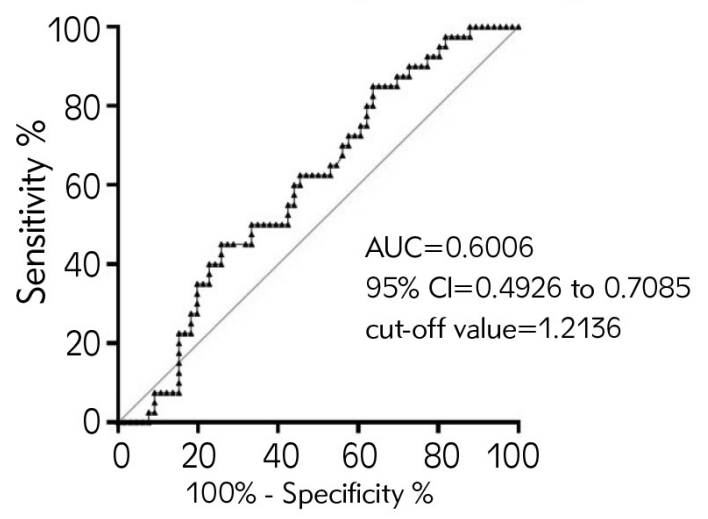

Figure 5 Potentials of aberrant miR-378 and miR-575 regarding surgical outcomes in EP. (A) AUC result of miR-378 in Engel I-II epilepsy versus Engel III-IV EP patients. (B) AUC result of miR-575 in Engel I-II epilepsy versus Engel III-IV EP patients.

tosis were jointly involved $(25,26)$. Current studies have shown that a variety of miRNAs are involved in the development of EP. MiR-132 was the first identified miRNA in EP, and its increase led to the development of EP (27). Furthermore, it was found that miR34a, miR-132, miR-146a, and miR-184 miRNA expression were upregulated after the seizure, further promoting the recurrence of EP (28). Meanwhile, miR-124 is decreased in EP, inhibiting seizure activity through targeting CREB1 (29). Our study found that miR-378 and miR-575 were significantly reduced in serum samples from EP patients in relation to those in healthy controls, which was consistent with a previous study. Similar to our study, another study reported that miR-378 serves as a prognostic biomarker in cholangiocarcinoma (30).

Meanwhile, the clinical utility of microRNA-378 as an early diagnostic biomarker of human cancers has also been documented (31). Furthermore, miR378 in serum are potential biomarkers for renal cell carcinoma (32). Additionally, it has been found that miR-378 play a role in metabolism, angiogenesis,

\section{References}

1. Beghi E, Giussani G, Sander JW. The natural history and prognosis of epilepsy. Epileptic Disord 2015; 17: 24353.

2. Boison D, Steinhäuser C. Epilepsy and astrocyte energy metabolism. Glia 2018; 66: 1235-43.

3. Cheng $Y$, Mai $Q$, Zeng $X$, et al. Propionate relieves pentylenetetrazol-induced seizures, consequent mitochondrial disruption, neuron necrosis and neurological deficits in mice. Biochem Pharmacol 2019; 169: 113607. and muscle biology (33). Similarly, miR-575 serve as a diagnostic marker for metastatic breast cancer and pancreatic cancer $(34,35)$.

Meanwhile, the ROC analysis validated that miR-378 and miR-575 may be highly sensitive and non-invasive candidates for EP diagnosis. More importantly, according to the Engel guidelines and dynamic changes in miR-378 and miR-575 before and after surgery treatment, we confirmed the potentials of miR-378 and miR-575 in predicting surgery outcome and treatment response in EP as well.

To sum up, miR-378 and miR-575 were decreased in EP serum samples, functioning as feasible biomarkers for EP monitoring and predicting surgical prognosis.

\section{Conflict of interest statement}

The authors reported no conflict of interest regarding the publication of this article.

4. Li W, Hao N, Xiao Y, Zhou D. Clinical characteristics and pregnancy outcomes of new onset epilepsy during pregnancy. Medicine (Baltimore), 2019; 98: e16156.

5. Symonds JD, Zuberi SM, Stewart K, et al. Incidence and phenotypes of childhood-onset genetic epilepsies: a prospective population-based national cohort. Brain 2019; 142: 2303-18.

6. Zijlmans M, Zweiphenning W, van Klink N. Changing concepts in presurgical assessment for epilepsy surgery. Nat Rev Neurol 2019; 15: 594-606. 
7. Supriya S, Siuly S, Wang H, Zhang Y. Epilepsy Detection from EEG using Complex Network Techniques: A Review. IEEE Rev Biomed Eng Pp 2021.

8. Ghafouri-Fard S, Shoorei H, Taheri M, Sanak M. Emerging role of non-coding RNAs in allergic disorders. Biomed Pharmacother 2020; 130: 110615.

9. Jonas S, Izaurralde E. Towards a molecular understanding of microRNA-mediated gene silencing. Nat Rev Genet 2015; 16: 421-33.

10. Wang J, Zhang C, Peng X, et al. A combination of four serum miRNAs for screening of lung adenocarcinoma. Hum Cell 2020; 33: 830-8.

11. Condrat CE, Thompson DC, Barbu MG, et al. miRNAs as Biomarkers in Disease: Latest Findings Regarding Their Role in Diagnosis and Prognosis. Cells 2020; 9: 31979244.

12. Ma Y. The Challenge of microRNA as a Biomarker of Epilepsy. Curr Neuropharmacol 2018; 16: 37-42.

13. Wang J, Yu JT, Tan L, et al. Genome-wide circulating microRNA expression profiling indicates biomarkers for epilepsy. Sci Rep 2015; 5: 9522.

14. Huang WS, Zhu L. MiR-134 expression and changes in inflammatory cytokines of rats with epileptic seizures. Eur Rev Med Pharmacol Sci 2018; 22: 3479-84.

15. Zhang X, Li X, Li B, Sun C, Zhang P. miR-21-5p protects hippocampal neurons of epileptic rats via inhibiting STAT3 expression. Adv Clin Exp Med 2020; 29: 793-801.

16. Cattani AA, Allene $C$, Seifert $V$, et al. Involvement of microRNAs in epileptogenesis. Epilepsia 2016; 57: 1015-26.

17. Henshall DC, Hamer HM, Pasterkamp RJ, et al. MicroRNAs in epilepsy: pathophysiology and clinical utility. Lancet Neurol 2016; 15: 1368-76.

18. Sun J, Cheng W, Liu L, et al. Identification of serum miRNAs differentially expressed in human epilepsy at seizure onset and post-seizure. Mol Med Rep 2016; 14: 5318-24.

19. Thijs RD, Surges R, O'Brien TJ, Sander JW. Epilepsy in adults. Lancet 2019; 393: 689-701.

20. Song $P$, Liu $Y, Y u X$, et al. Prevalence of epilepsy in China between 1990 and 2015: A systematic review and metaanalysis. J Glob Health 7, 2017; 020706.

21. Zhao R, Xue P, Zhou Y, et al. Application of RobotAssisted Frameless Stereoelectroencephalography Based on Multimodal Image Guidance in Pediatric Refractory Epilepsy: Experience of a Pediatric Center in a Developing Country. World Neurosurg 2020; 140; e161-e168.
22. Padmanaban V, Inati S, Ksendzovsky A, Zaghloul K. Clinical advances in photosensitive epilepsy. Brain Res 2019; 1703: 18-25.

23. Wijnen BFM, van Mastrigt G, Evers $S$, et al. A systematic review of economic evaluations of treatments for patients with epilepsy. Epilepsia 2017; 58: 706-26.

24. Nolan SJ, Tudur Smith C, Weston J, Marson AG. Lamotrigine versus carbamazepine monotherapy for epilepsy: an individual participant data review. Cochrane Database Syst Rev 2016; 11: Cd001031.

25. Wei $H, X u Y, C h e n Q$, et al. Mesenchymal stem cellderived exosomal miR-223 regulates neuronal cell apoptosis. Cell Death Dis 2020; 11: 290.

26. Ye $Y, X u H$, Su X, He X. Role of MicroRNA in Governing Synaptic Plasticity. Neural Plast 2016, 4959523.

27. Wang X, Zhou Y, Gao Q, et al. The Role of Exosomal microRNAs and Oxidative Stress in Neurodegenerative Diseases. Oxid Med Cell Longev 2020; 3232869.

28. Galardi A, Colletti M, Businaro P, et al. MicroRNAs in Neuroblastoma: Biomarkers with Therapeutic Potential. Curr Med Chem 2018; 25: 584-600.

29. Sueri C, Gasparini S, Balestrini S, et al. Diagnostic Biomarkers of Epilepsy. Curr Pharm Biotechnol 2018; 19: 440-50.

30. Zhou Z, Ma J. miR-378 serves as a prognostic biomarker in cholangiocarcinoma and promotes tumor proliferation, migration, and invasion. Cancer Biomark 2019; 24(2): 173-81.

31. Li Z, Shen L, Li Y, et al. Clinical utility of microRNA-378 as early diagnostic biomarker of human cancers: a metaanalysis of diagnostic test. Oncotarget 2016; 7(36): 58569-78.

32. Redova M, Poprach A, Nekvindova J, et al. Circulating miR-378 and miR-451 in serum are potential biomarkers for renal cell carcinoma. J Transl Med 2012; 22: 10:55.

33. Krist B, Florczyk U, Pietraszek-Gremplewicz K, et al. The Role of miR-378a in Metabolism, Angiogenesis, and Muscle Biology. Int J Endocrinol 2015; 281756.

34. Satomi-Tsushita N, Shimomura A, Matsuzaki J, et al. Serum microRNA-based prediction of responsiveness to eribulin in metastatic breast cancer. PLoS One 2019; 4: 14(9), e0222024.

35. Yan Q, Hu D, Li M, et al. The Serum MicroRNA Signatures for Pancreatic Cancer Detection and Operability Evaluation. Front Bioeng Biotechnol 2020; 29: 8:379. 